\title{
Doğal ve Kültürel Kent Kimliklerinin Belirlenmesi: Edirne İli Karaağaç Mahallesi Örneği
}

\author{
Nilay MISIRLI $^{1 *}$, Tuğba KİPER ${ }^{1}$, Aslı KORKUT $^{1}$ \\ 1 Tekirdağ Namık Kemal Üniversitesi, Güzel Sanatlar, Tasarım ve Mimarlık Fakültesi, Peyzaj Mimarlı̆̆ı \\ Bölümü, 59030, TEKIRDA $\breve{G}$
}

Öz

Bu çalışma kapsamında, bir yerleşimin sahip olduğu doğal, kültürel özellikler ve barındırdığı kimlik öğelerinin irdelenmesi, kaybolmaya yüz tutmuş değerlerinin tekrar ortaya çıkarılması ve mevcut özelliklerinin de korunarak geleceğe aktarılması hedeflenmektedir. Çalışma içerisinde, özgün doğal ve kültürel değerlere sahip Edirne İli Karaağaç Mahallesi'nin kimlik öğelerinin belirlenerek ileriye dönük yapılacak planlama çalışmalarına bir altlık oluşturmak amaçlanmıştır. Bu amaçla, konu ve alanla ilgili literatür araştırmalarından, resmî kurumlardan elde edilen verilerden ve yerinde yapılan arazi tespit çalışmalarından yararlanılmıştır. Çalışma kapsamında örnek alana ilişkin; ulaşım durumu, yerleşim dokusu, doluluk-boşluk analizi, kat yükseklikleri analizi, nüfus yoğunlukları analizi, kentsel sit alanı ve tescilli yapılar ile doğal sit alanları bulgularına ilişkin haritalar hazırlanarak, mevcut durum tespiti yapılmışıtır. Elde edilen bulgular doğrultusunda alana iliş̧kin güçlü ve zayıf yönler belirlenerek, alanın kimlik değerlerinin güçlenmesine yönelik çeşitli öneriler geliştirilmiştir.

Anahtar Kelimeler: Kimlik, Edirne, Karaağaç Mahallesi.

\section{Identification of Natural and Cultural Urban Identity: A Case Study of Edirne Karaağaç Neighborhood}

\begin{abstract}
In this study; it is aimed to create a base for future planning which will be carried out for determination of identity elements of Edirne Karaağaç Neighborhood. For this purpose, studies have been used from literature researches, data obtained from official institutions and survey. Within the scope of the study, the existing situation has been analyzed by preparing maps related to the findings of transportation information, settlement pattern analysis, solid-void analysis, number of storey analysis, population density analysis, urban site and registered structures, natural sites. By identifying the strengths and weaknesses of the field in the direction of the findings, various proposals have been developed to strengthen the identity values of the area.
\end{abstract}

Keywords: Identity, Edirne, Karaağaç Neighborhood. 


\section{Giriş}

Kent, topluluk olarak yaşayan insanların, ortak yaşamlarından doğan ve onların yaşam biçimleri ile toplumsal, ekonomik, yönetimsel, çevresel birçok farklı sürecin etkileşimi sonucunda şekillenen mekândır. Mekân ise; insanı biçimlendiren ve onun tarafindan biçimlendirilen toplumsal bir boyuttur" (Harvey, 2003). Kentler, Tarihi, sosyal, kültürel, siyasi özellikleri bünyesinde barındıran, belli bir nüfus büyüklüğüne ve nüfus yoğunluğuna erişmiş yaşama ortamlarını oluştururlar (Kaya, 2017). Kentler, bireyler için barınma, korunma, eğitim, çalışma, ticaret, sosyal ve kültürel fonksiyonlar gibi pek çok alanda hizmet sunmaktadır (Bulut ve Atabeyoğlu, 2010). Tarih boyunca gelişen süreçte ve dönemin özelliklerine göre farklı biçimler, anlamlar kazanarak dinamik bir yapı oluşturmaktadırlar (Özkök, 2016). Bu anlamda kentler, geçmişteki olayların yaşandığı ve farklı deneyimlerin farklı biçimde ifade edildiği yerlerdir (Ringas vd., 2011).

Kentler, insanların yerleşme ve varlıklarını sürdürme konusundaki amaçlarına göre karakter kazanırlar (Gül, 2000). Çetinkaya ve Uzun'un aktarımı ile Andersson (2014); kentlerin ekolojik, ekonomik, sosyal ve kültürel faaliyetler içerdiğini bu faaliyetlerin de kent sisteminin ve kimliğinin oluşmasına ve şekillenmesine katkı sağladığını belirtmektedir (Çetinkaya ve Uzun, 2014).

Günümüzde plansız ve düzensiz kentleşme ile bireylerin doğal çevreye dayalı fiziksel ve sosyal ihtiyaçlarını karşılayabileceği doğal kaynaklar tükenmekte, bu ise insanların fiziksel ve ruhsal sağlığını, kent sistemini ve kimliğini olumsuz yönde etkilemektedir. Hızlı kentleşme, kırdan kente göçler sonucu kentlerdeki nüfusun artışı ve yanlış alan kullanımları vb. nedenler kentin parçası olan yeşil alanları da yok etmektedir. Kentsel yeşil alanlar; kentsel biyoçeşitliliği desteklemekte, gürültü kontrolünü sağlamakta, karbondioksiti hapsetmekte, oksijen üretmekte, mikroklimayı düzenlenmekte, ısı adalarının oluşmasını engellemekte ve selleri azaltmakta, yaban hayatı ortamı sağlamakta, kronik hastalıkları önlemekte, ölüm oranını azaltmakta ve kentlerin görünümüne estetik katkılar sağlamaktadır (Karaşah, 2017). Çözüm olarak, yapay çevreye doğal gereksinme kaynaklarını dengeli olarak kazandıran planlama ve tasarım yaklaşımları benimsenmeli ve yaygınlaştırılmalıdır (Öztürk Tel ve Erdoğan, 2014).

$\mathrm{Bu}$ bağlamda üst ölçekli çalışma alanı olarak Edirne kenti seçilmiştir. Birçok medeniyete ev sahipliği yapmış Edirne, Türkiye'nin batı sınırına en yakın yerleşmesi olarak bölge ve ülke açısından önemli bir transit merkezi; ülkenin Avrupa'ya açılan kapısı niteliğindedir. Yaklaşık 90 yıl boyunca Osmanlı İmparatorluğu'na başkentlik yapmış; Osmanlı mimarisinin görkemli dini yapıları ve sivil mimarlık örnekleri ile ön plana çıkmıştır. Eski Camii, Üç Şerefeli Camii, Muradiye Camii, Dar'ül Hadis Cami ve Şehzadeler Türbesi gibi dini yapıları; Saatli Medrese ve Peykler Medresesi, Selimiye Külliyesi ve II. Bayezid Külliyesi gibi eğitim ve sosyo-kültürel yapıları; Rüstem Paşa Kervansarayı, Ekmekçizade Ahmet Paşa Kervansarayı ve Ali Paşa Arastası gibi ticari yapıları; Sv. Konstantin ve Helena Kilisesi, Sv. Yorgi Kilisesi ve Büyük Sinagog gibi azınlık yapıları; Meriç ve Tunca Köprüleri, Fatih ve Kanuni Köprüleri, Hacı Adil Bey Çeşmesi gibi su yapıları yanı sıra çok sayıdaki sivil mimarlık örnekleri kentin yapay kimlik bileşenleri arasındadır (Mısırlı ve Benian, 2014).

Meriç ve Tunca Nehirleri, Edirne Kent Ormanı ve Sarayiçi Tavuk Ormanı gibi doğal kimlik bileşenleri de kentin diğer kimlik elemanları arasındadır. UNESCO Somut Olmayan Kültür Mirası listesinde yer alan "Kırkpınar Yağlı Güreşleri” ise kimliği oluşturan kültürel bileşenler içerisinde bulunmaktadır.

Sıralanan özellikler doğrultusunda Edirne kent merkezinde "tarihi kent” kimliği olgusu baskın karakter göstermektedir. Ayrıca Yunanistan ve Bulgaristan ile sınır oluşturması Edirne için "sınır kenti” kimliğini de vurgulamaktadır.

Kent kimliği, geçmişten günümüze kadar geçen sürede oluşup, gelişmektedir. Bu süreç içerisinde kentler, hızlı kentleşme, göç, plansız yapılaşma, teknolojinin gelişimi, kaynakların bilinçsiz kullanımı gibi birçok neden ile fiziksel, sosyal, ekonomik değişimler yaşamaktadır. Yaşanan değişimler, kent ve kimliğine olumlu veya olumsuz etkiler yaratmaktadır. Olumsuz etkilerin kent kimliğinin bozulmasına hatta kimi zaman yok olmasına neden olduğu görülmektedir. Bu durum kent kullanıcı kitlesine de etki etmektedir.

$\mathrm{Bu}$ temel bilgiler bağlamında çalışma kapsamında bir yerleşimin sahip olduğu doğal, kültürel özellikler ve barındırdığı kimlik öğelerinin irdelenerek kaybolmaya yüz tutmuş değerlerinin tekrar ortaya çıkarılması, mevcut özelliklerinin de korunarak geleceğe aktarılması hedeflenmektedir. Bu çalışmada özgün doğal ve kültürel değerlere sahip Edirne İli Karaağaç Mahallesi'nin kimlik öğelerinin belirlenerek ileriye dönük yapılacak planlama çalışmalarına bir altlık oluşturması amaçlanmıştır. 


\subsection{Kent kimliği olgusu ve bileşenleri}

Kent kimliği; kent imajına etki eden, kentin ölçeğine ve barındırdığı özgün niteliklere göre yorumlanan; fiziksel, kültürel, sosyo-ekonomik, tarihsel ve biçimsel faktörlerin yön verdiği; oluşmasında kent sakinlerinin yaşam biçiminin etkili olduğu, sürekli gelişen ve sürdürülebilir kent kavramını yaşatan, geçmiş ile gelecek arasında bağ kuran olgudur (Çöl, 1998). Kimlik, o "şeye" ait özellikleri taşır ve bütün içinden algılanabilme bu kimlik sayesinde olmaktadır.

Bir kentin kimliğe sahip olması ile (Demir, 2006);

- Kentin diğer kentler arasından ayrilıp, tanınır hale gelmesi,

- Kent kimliğine uygun biçimde büyüme modeli geliştirilmesi,

- Kentin var olan kimliğine zarar verecek kullanımların reddedilmesi,

- Toplumsal duyarlılığın artması,

- Öngörülen yatırımlarda nitelik ve uygunluk aranmaya başlanması,

- Kent kaynaklarına paralel olarak kent kimliğinin gelişmesi sağlanmaktadır.

Bir kentin kimliği, tarihsel süreç ile bağıntılı olup, zaman içinde oluşmakta ve değişim göstermektedir. Yavaş gelişme gösteren, uzun bir tarihsel geçmişi olan kentlerin zamanın değişik katmanlarının üst üste çakışmasıyla oluşmuş bir kimliğe sahip olduğu ve bu kimliğin iyi korunduğu aynı zamanda geçmişin bir tekrarı olmadığı belirtilmektedir. Sürekli bir değişim içinde olan toplum ve insan iliş̧kileri bu kimlik olgusunun yenilenmesini sağlamaktadır. Bu tanımlamalar ile kimlik; geçmiş birikimleri, bunların yorumlarını ve yeni birikimleri kapsamaktadır (Tekeli, 1990).

Koyuncu'ya (2013) göre kentin kimliği; doğal ve yapay çevreden kaynaklanan kimlik elemanları, bu elemanların mekânsal öğeleri, tarihi, kültürü, coğrafyası, bitki örtüsü, iklimi, jeopolitik konumu, mimarisi, ekonomik düzeyi, sosyal, siyasi, etnik, dini yapısı, yaşam biçimi, dünya görüşü, beşiklik ettiği uygarlıklar, bu uygarlıklara başkentlik yapıp yapmadığı, başka kültürlerle etkileşimleri, geçirdiği işgaller, savaşlar, afetler vb. birçok etkene göre değişiklik göstermekte ve kendine has özellikler ortaya çıkmaktadır.

Kent kimliğini oluşturan bileşenler çeşitli başlıklar altında sınıflandırılmaktadır. Bu sınıflandırmaların; çevresel ve toplumsal kimlik elemanları, doğal, beşerî ve insan eliyle yapılmış çevreden kaynaklanan elemanlar, doğal ve beşerî-kültürel bileşenler, fiziksel/biçimsel ve sosyal bileşenler ile bunların etkileşimlerinden meydana gelen bileşenler gibi çok çeşitli değerlendirme biçimleri bulunmaktadır (Tablo 1) (Önem ve Kılınçaslan, 2005; Arabulan, 2015; Karakaya Aytin vd., 2016; Benli ve Özer, 2018). Hernandez (2007) de; peyzaj kimliğini oluşturan birbiri ile ilişsili üç temel bileşen olduğunu ve bunların arazi formu (jeoloji, topoğrafya ve erozyon, hidroloji vb. doğal süreçler ), arazi örtüsü (bitki örtüsü, su yüzeyleri ve toprak yapısı gibi biyolojik faktörler) ve alan kullanımı (tarım, turizm ve ulaşım gibi kültürel ve sosyal süreçler ve yere anlam kazandıran manevi ve tarihsel olaylar) şeklinde sinıflandırılabileceğini belirtmiştir (Hernandez, 2007). Yapılı çevrenin kimliği ile toplumun sosyal ve kültürel kimliği karşılıklı olarak birbirini etkilemektedir (Neill, 1997). Bu noktada çeşitli sınıflandırmalar yapılsa da kent kimliği; kentin doğal, yapay, sosyo-kültürel ve sosyo-ekonomik özellikleri ile bir bütün olarak ele alınmalıdır (Lynch, 1960). ICOMOS Québec Bildirgesi’nde ise; yapı, alan, peyzaj, güzergâh, obje ve manevi nitelikler; anı, anlatı, yazılı belge, tören, festival, geleneksel bilgi, değerler, doku, renk, iz, vb. özelliklerin birlikteliğinin yerin ruhunu, aynı zamanda yerel kimliği tanımladığı kabul edilmiştir (ICONOS, 2008: 2) 
Tablo 1. Kimlik bileşenlerinin belirlenmesinde yararlanılan kaynaklar (Ocakçı, 1994; Topçu, 2011; Arabulan, 2015; Karakaya Aytin vd., 2016; Güneroğlu ve Bekar, 2017)

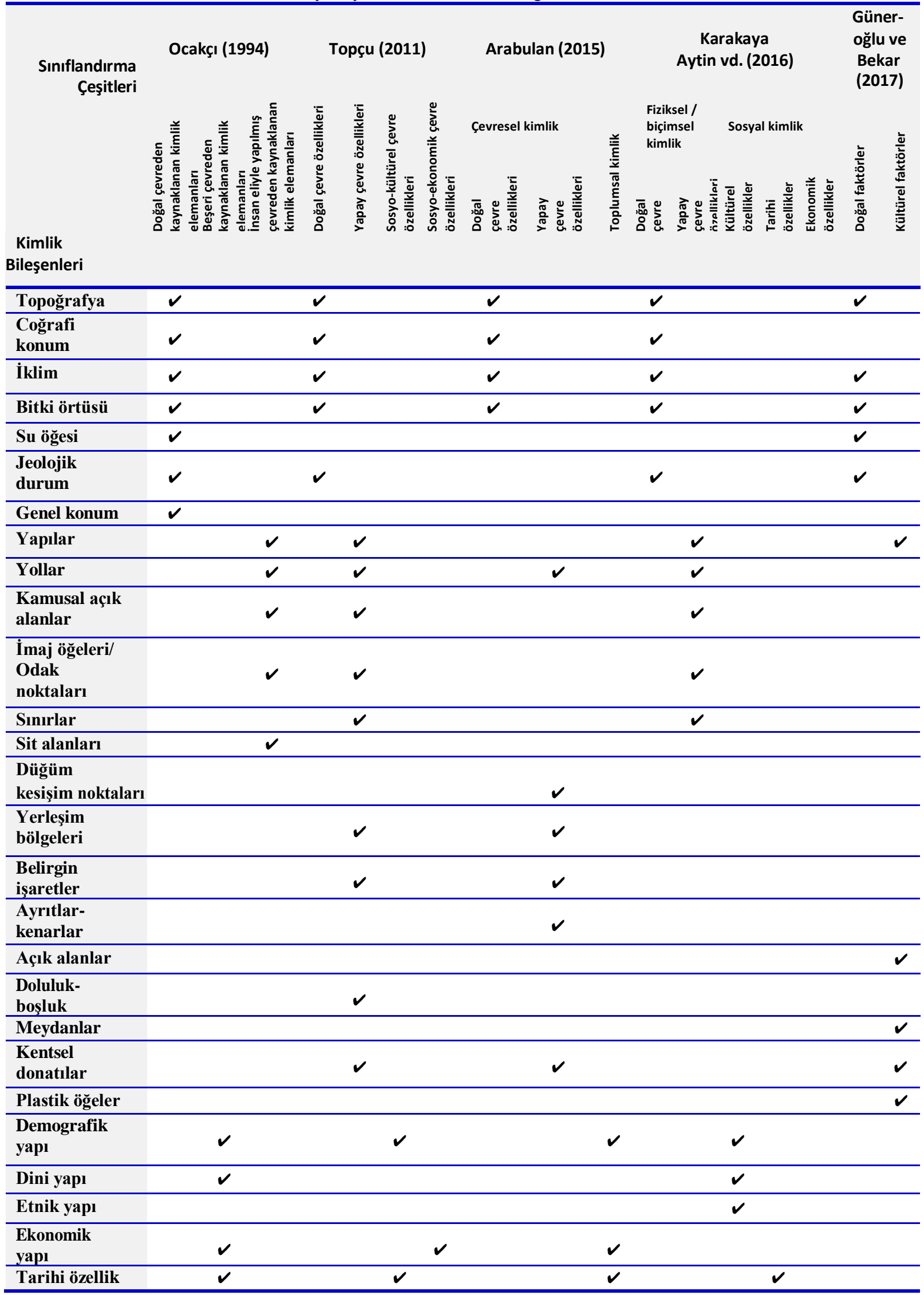


Tablo 1. Kimlik bileşenlerinin belirlenmesinde yararlanılan kaynaklar (Ocakçı, 1994; Topçu, 2011; Arabulan, 2015; Karakaya Aytin vd., 2016; Güneroğlu ve Bekar, 2017) (devamı)

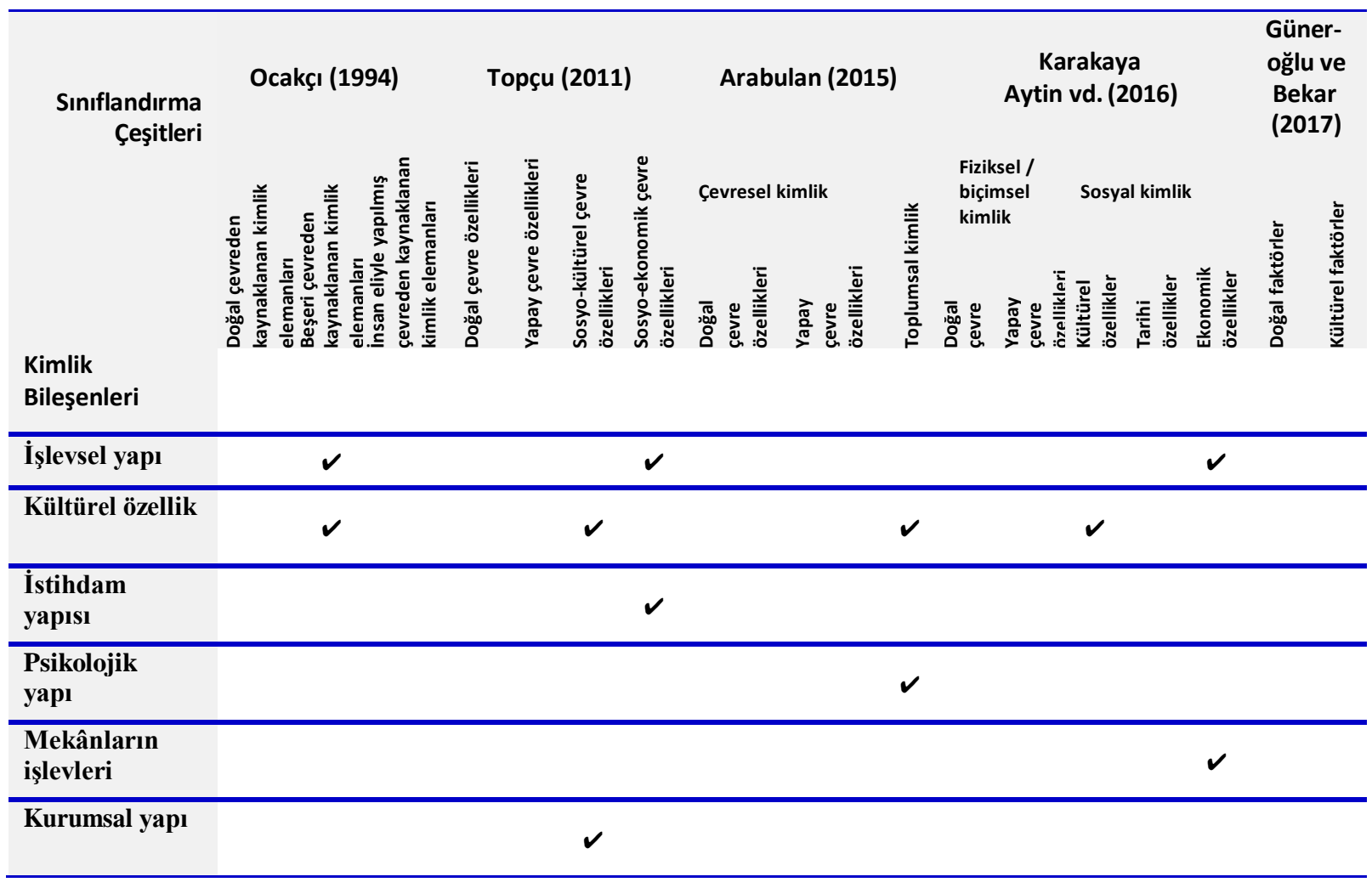

$\mathrm{Bu}$ açıklamalar doğrultusunda çalışma içerisinde kimliği oluşturan bileşenler iki başlık altında incelenmektedir. Bunlar topoğrafik durum, iklim koşulları, bitki örtüsü, jeolojik yapı, dini yapı, etnik yapı, gelenek ve görenekler gibi dışarıdan müdahale edilmeden kendi kendine oluşmuş doğal kimlik elemanları ve yapay çevre elemanları (yapılar, yollar, kamusal açık alanlar, imaj öğeleri, sınırlar...), demografik yapı (nüfus büyüklüğü, yapısı, yoğunluğu, yaş grupları...), kurumsal yapı (politik, yönetsel, hukuksal, ekonomik...) gibi müdahale sonucu oluşmuş yapay kimlik elemanlarıdır.

Çalışmanın bulgular bölümünde Edirne İli Karaağaç Mahallesi kent kimliğini oluşturan bileşenler kapsamında incelenmektedir

\section{Materyal ve Metot}

\subsection{Materyal}

Araştırma ana materyalini, Edirne İli Karaağaç Mahallesi oluşturmaktadır. Karaağaç Mahallesi, Edirne’nin yaklaşık 5 km güneybatısında, Meriç Nehiri’nin batı yakasında yer almaktadır. Karaağaç Mahallesi sınırları; kuzeyde Meriç Nehri, güneyde Sinekli Sınır Karakolu, batıda Pazarkule’ye kadar uzanmaktadır (Şekil 1).

Araştırma alanı, Edirne İlini oluşturan 24 mahalleden birisidir. 2300 hektarlık alanı ile Edirne'nin yüzölçümü bakımından en büyük mahallesi Karaağaç'tır. Yerleşim alanı ise 125 hektar bir alan kaplamaktadır (Şekil 2) (Arabulan, 2015). 


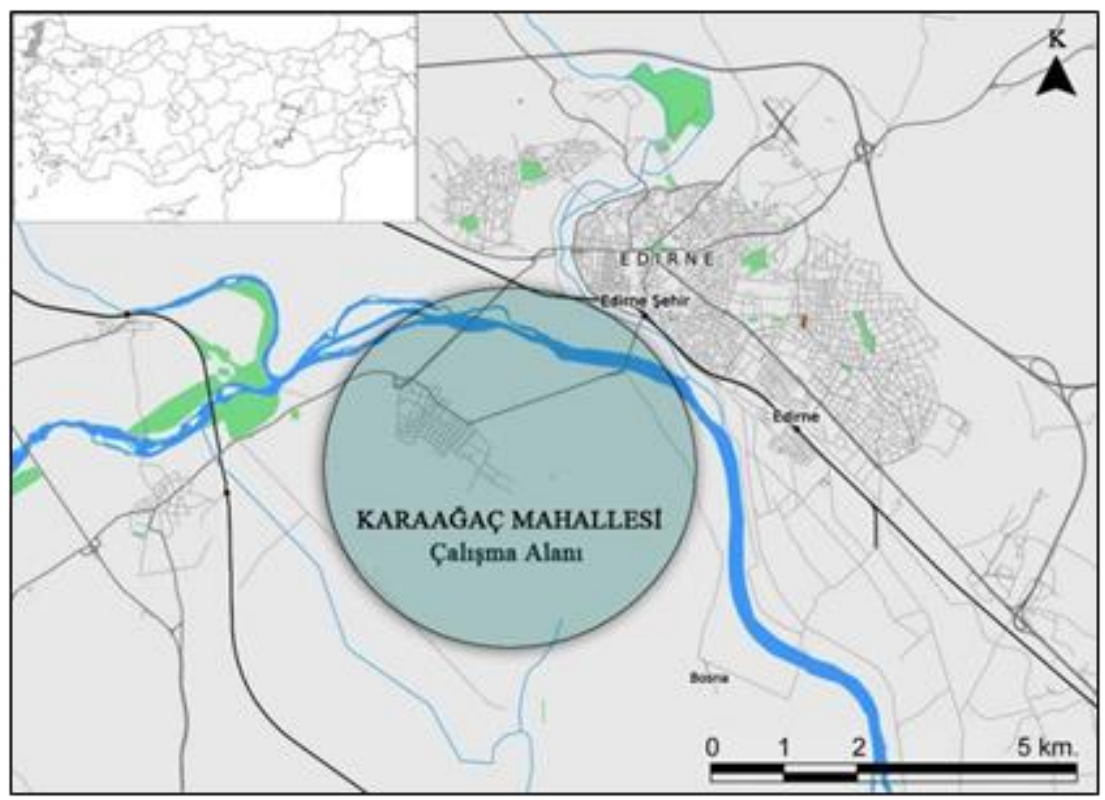

Şekil 1. Çalışma alanı coğrafi konumu

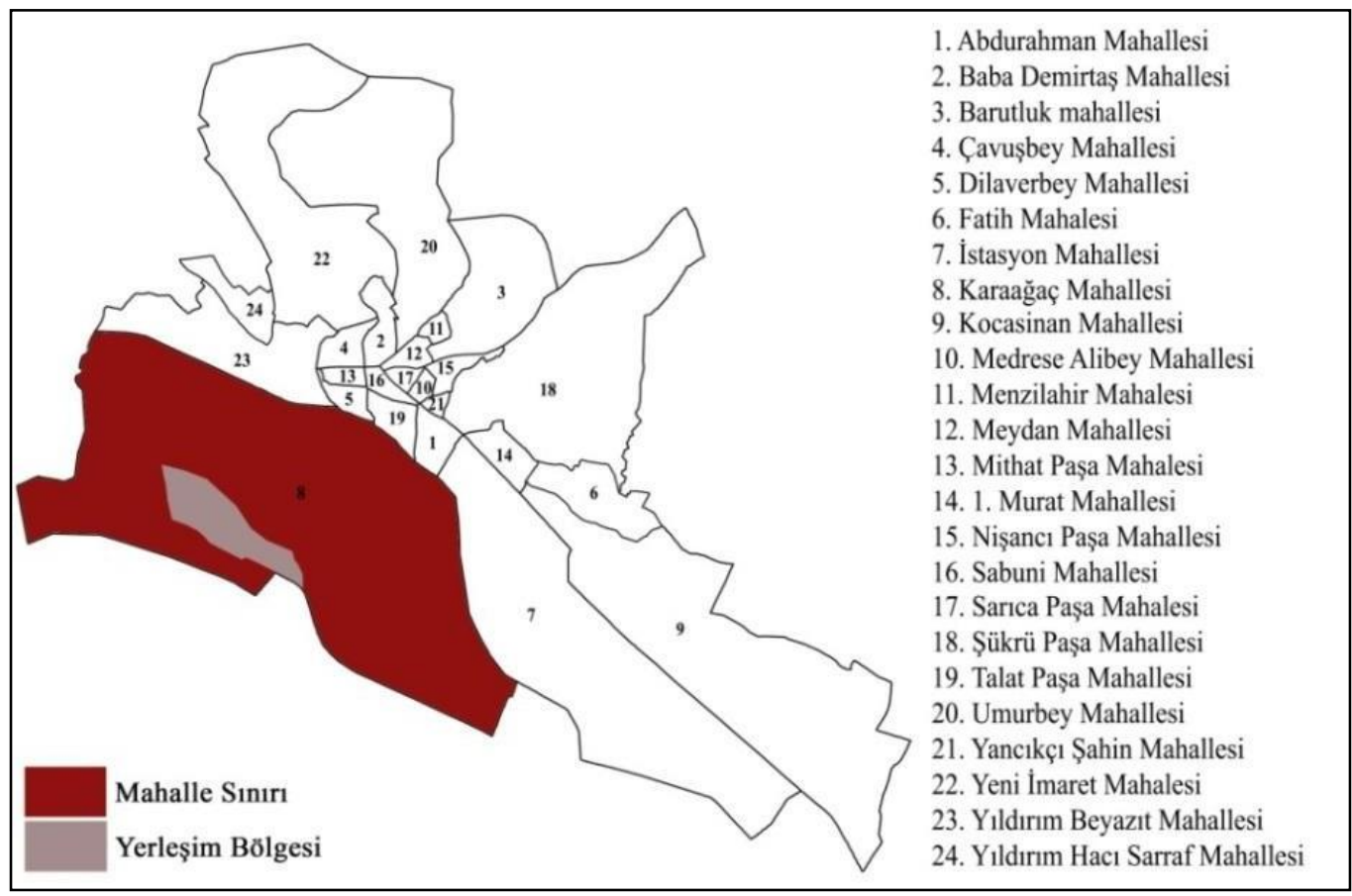

Şekil 2. Edirne mahalleleri ve Karaağaç Mahallesi sınırı ve yerleşim bölgesi

Karaağaç mahallesinin araştırma alanı olarak seçilmesinin nedenleri aşağıda sıralanmıştır;

- Edirne İlinin yüzölçümü bakımından en büyük mahallesi olması (2300 ha, yerleşim alanı 125 ha) (Arabulan, 2015),

- Meriç Nehri'nin büyük bir bölümünün alan içinden geçmesi,

- Tunca Nehri sınırları içerisinde yer alması,

- Doğal sit alanlarına sahip olması (Asker Söğütlüğü Devlet Ormanı, Pazarkule Devlet Ormanı, Karaağaç Söğ̈̈tlüğü Devlet Ormanı),

- Alanın bir bölümünün Kentsel Sit Alanı olarak koruma altına alınmış olması,

- Yunanistan ile sınır bölgesi içerisinde yer alması (Pazarkule sınır kapısı),

- Kentsel imge niteliğinde landmarkların (nirengi noktaları) bulması (Tarihi tren garı, Lozan Anıtı). 
Çalışma kapsamında; Edirne İli Karaağaç yerleşiminin yerel kimlik değerlerinin tespitine yönelik değerlendirmeler yapılmıştır. Bu doğrultuda çalışma, literatür ve mekana yönelik çeşitli analizlerin yapıldığı arazi çalışmaları ile desteklenmiştir. Çalışma metodu; çalışmanın amaç ve öneminin belirlenmesi, verilerin toplanması, verilerin değerlendirilerek mekânsal analizlerin yapılması ile sonuç ve önerilerin geliştirilmesi çerçevesinde oluşturulmuştur. Bu kapsamda, kendine özgü doğal ve kültürel değerleri ile önem teşkil eden Edirne İli Karaağaç Mahallesi'nin kimlik öğelerinin belirlenerek ileriye dönük yapılacak planlama çalışmalarında yol gösterici olması hedeflenmiştir. Konu ve alanla ilgili çeşitli kitap, makale, tez, araştırma gibi yazılı kaynaklardan yararlanılarak literatür verilerinin değerlendirilmesi yapılmıştır. Literatür araştırmalarından, yerinde tespit ve resmî kurumlardan elde edilen verilerden yararlanılıp Edirne mahalleleri, Edirne mahalleleri nüfus yoğunlukları, çalışma alanı ulaşım bilgileri, gridal plan şeması, doluluk-boşluk analizi, kat analizi, kentsel sit alanı ve tescilli yapılar, doğal sit alanları bulgularına ilişkin haritalar hazırlanarak mevcut durum analiz edilmiştir. Araştırma için gerekli olan haritalama çalışmaları kapsamında, Edirne kent merkezine ait mevcut hâlihazır haritalar içerisinde Karaağaç Mahallesi'ne ait bölümün yer almadığı görülmektedir. Mahallenin yerleşim alanına ait haritalar mevcuttur. Bu haritaların kent merkezi ile ilişkisinin yer aldığı haritaların olmaması araştırmanın kısıtları arasındadır. Son aşamada, elde edilen tüm veriler ve hazırlanan haritalar doğrultusunda çalışma alanı için çeşitli öneriler geliştirilmiştir.

\section{Bulgular ve Tartışma}

\subsection{Doğal ve yapay kimlik elemanlarına ilişkin bulgular}

Karaağaç’ın tarihi hakkında bilgiler 17. yüzyılın ikinci yarısına kadar yok denilecek kadar az olduğu söylenmektedir. Geçmişte "Maraş" ya da "Eski Maraş" adı ile anılan yerleşimin 16. yüzyılda "Karaağaç'a" dönüştürüldüğü bilinmektedir. 17. yüzyılda Karaağaç'ın bir Rum Köyü olduğu, Edirnelilerin yazlık evlerinin bu köyde bulunduğu ve Edirne için mesirelik ve eğlence bölgesi özelliği gösterdiği belirtilmektedir. 19. yüzyıl içinde, İstanbul'u Avrupa'ya bağlayan tren yolu için Edirne Garı'nın Karaağaç'a yapılmasından sonra bölgede yapılaşmanın arttığı belirtilmektedir. Yapılaşma ile birlikte ticari faaliyetler artmış ve geniş bir alana yayılan dutluklar ile ipekböceği üretimi görülmüştür. İpekböcekciliği üretimine yönelik olarak da; Demirtaş köyü ile Karaağaç arasından geçen ve Sinekli'ye uzanan yol üstünde büyük bir koza işleme fabrikası yer aldığı belirtilmektedir. Ayrıca, Ortaköy Caddesi üzerinde bulunan baca kalıntısının yine bu dönemlerde kullanılan bir başka koza fabrikasına ait olduğunu göstermektedir (Şekil 3) (Emekligil Erdoğu, 2013).

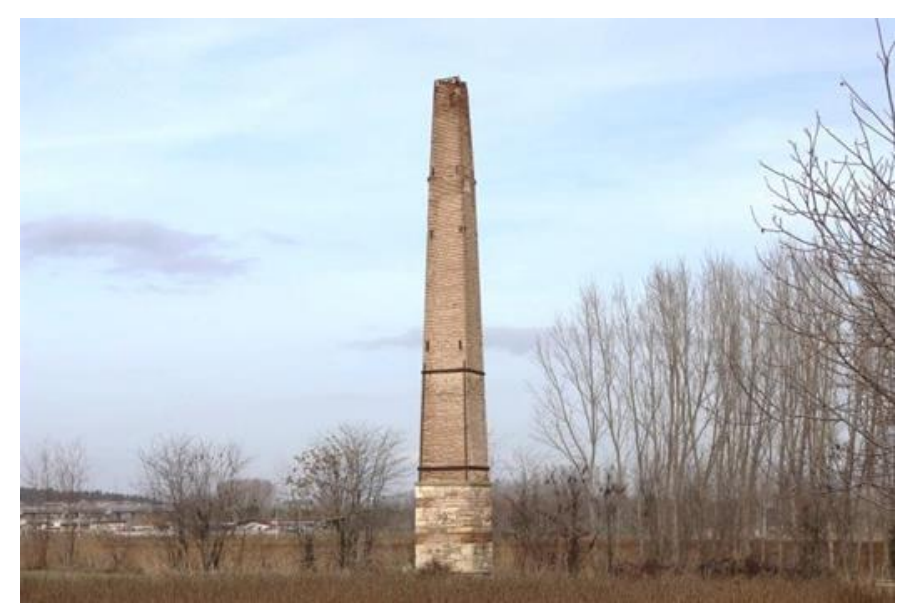

Şekil 3. Ortaköy Caddesi üzerinde bulunan baca kalıntısı

1920-23 yılları arasında Yunan işgali altında kalan Karaağaç, Lozan Anlaşması'ndan sonra, savaş tazminatı olarak 15 Eylül 1923 'de Türk hükümetine devredilmiştir. 1923 Mübadelesinden sonra, Edirne'ye bağlı bir mahalle konumuna gelen Karaağaç'ta kalan, gayrimüslim halkın büyük bir kısmı, II. Dünya Savaşı sıralarında göç etmişlerdir. Mübadele ile Batı Trakya'dan gelen Müslüman halkın bir bölümü ise Karaağaç’a yerleştirilmiştir (Emekligil Erdoğu, 2013).

Karaağaç Mahallesi, düz bir topoğrafya üzerinde kurulmuştur. Mahallede karasal iklim tipi hâkim olarak görülmektedir. Edirne tarihi merkezine oranla yüksek bir mevkide bulunması, orman ve nehirlerle çevrilmiş olması sebebiyle Karaağaç'da karasal iklimin etkileri daha fazla görülmektedir. Karaağaç Mahallesi’nin 2300 hektar alana sahip olan yüzölçümünün 125 hektarlık bölümünü yerleşim alanı sınırları oluşturmaktadır. Mahalle 
içerisinde yer alan yerleșim alanı kompakt bir yapıya sahiptir. Mahalle sınırları içerisinden Meriç Nehri ve Tunca Nehri geçmekte, Tunca Nehri bir noktada Meriç Nehri'ne katılarak akışına devam etmektedir (Şekil 4).
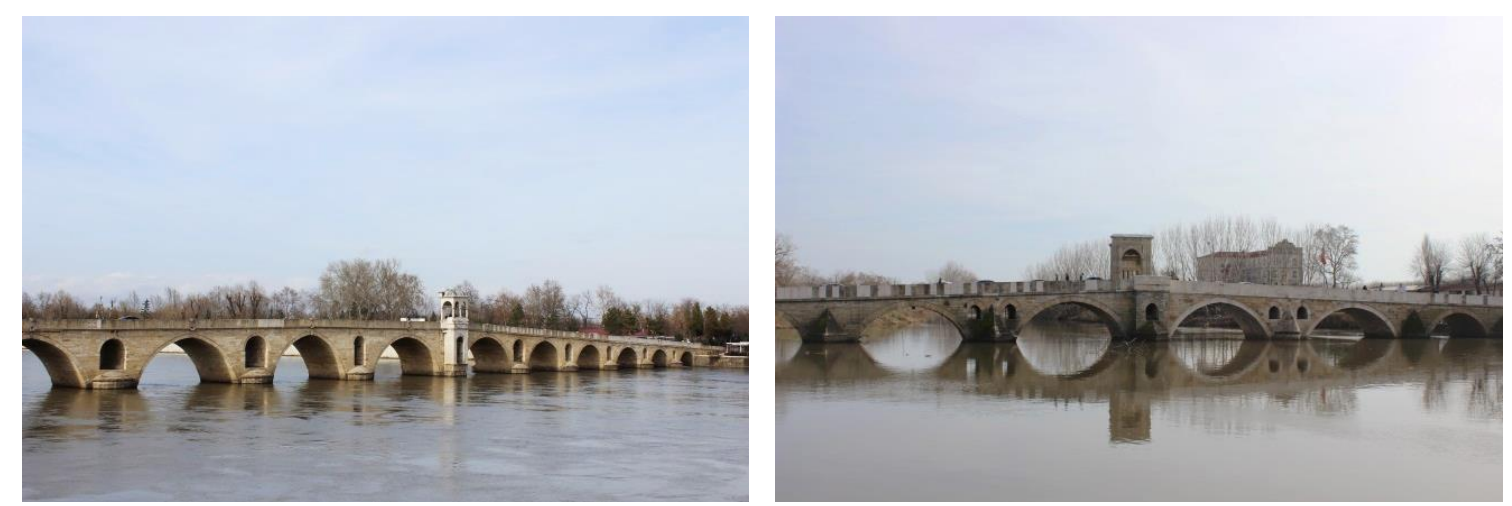

Şekil 4. Meriç Nehri-Köprüsü ve Tunca Nehri-Köprüsü

Meriç Nehri'nde kış aylarında yaşanan taşkın sorunları Karaağaç Mahallesi için bir tehdit oluşturmaktadır. Taşmanın yaşanması, ticaret alanları ile bazı konut bölgelerinin kullanımını engellemektedir. Taşkınlar, Mahalle ile kent merkezi bağlantısını nerdeyse kopartacak kadar engellemekte, askeri araçlar ile geçiş sağlanmaktadır. Karaağaç Mahallesi yerleşim bölgesi girişinde hayata geçirilen "Kanal Edirne" projesi ile bu taşkın sorununa çözüm üretilmesi düşünülmektedir.

Asker Söğütlüğü Devlet Ormanı (13 ha), Pazarkule Devlet Ormanı (16,5 ha), Karaağaç Söğütlüğü Devlet Ormanı (65 ha) olmak üzere toplam 94,5 hektarlık alan, mahallenin doğal sit alanı sınırlarını oluşturmaktadır (Şekil 5) (Edirne Orman Genel Müdürlüğü Arşivi, 2017). Mahallenin içerisinde kalan yaklaşık 2080 hektar alanı ise tarım alanları kaplamaktadır.

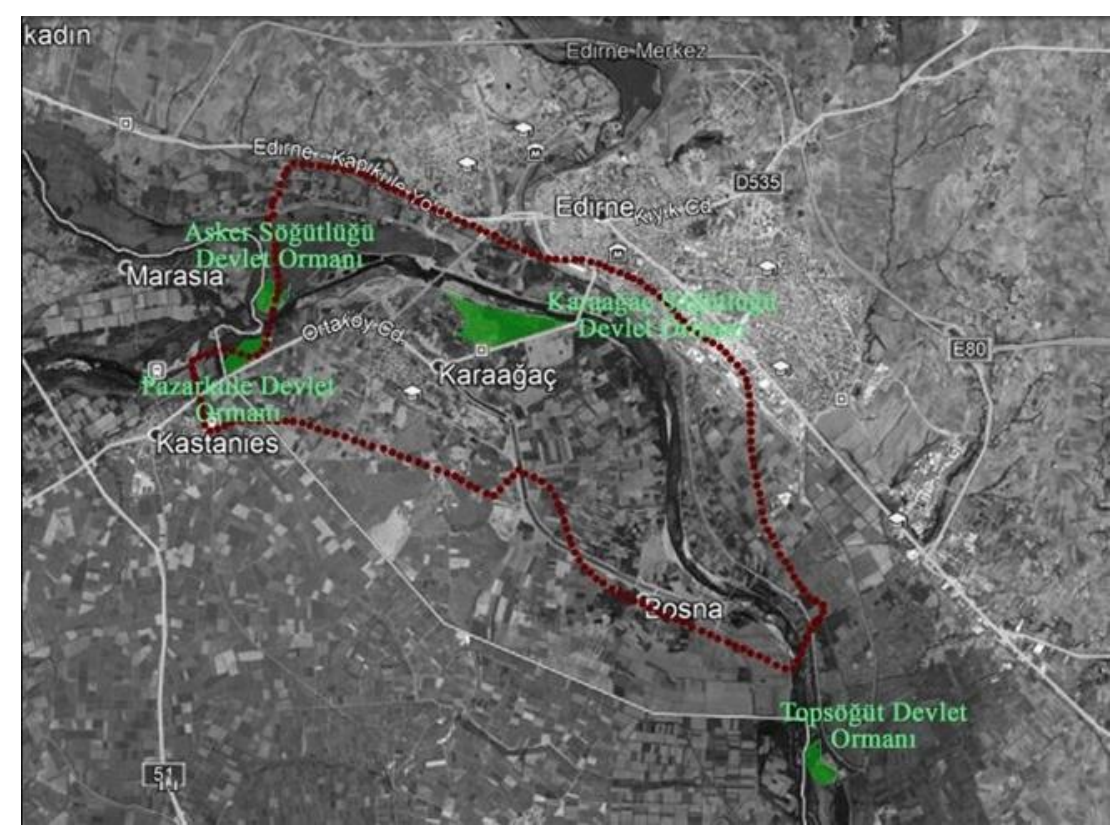

Şekil 5. Karaağaç Mahallesi doğal sit alanları (Edirne Orman Genel Müdürlüğü Arşivi 2017’den düzenlenmiştir)

Çamur (2000)'e göre, alanının doğal bitki dokusuna ilişkin olarak yapmış olduğu çalışmada (Etli ve Şişman 2004);

- Ak söğüt (Salix alba),

- Saplı Meyveli Karaağaç (Ulmus leavis Pall.),

- Ova Karaağacı (Ulmus minor Miller),

- Dişbudak yapraklı Akçaağaç (Acer negundo L.),

- Erguvan (Cercis siliquastrum),

- Titrek Kavak (Populus tremula) gibi türler yer almaktadır. 
Alanda ayrıca (Kiper ve Öztürk, 2011);

- Yabani Erik (Prunus spinosa L.),

- Armut (Pyrus eleagnifolia Pall.),

- Muşmula (Mespilus germanica L.) gibi meyve ağaçları da mevcuttur.

Edirne kent merkezinden Karaağaç Mahallesine ulaşım, Tunca ve Meriç Nehir yataklarının bir bölümünün mahalle sınırları içerisinden geçmesi sebebi ile Karaağaç Viyadüğü ile tarihi Tunca Köprüsü (1608-1613) ve Meriç Köprüsü’nden (1842-1847) sağlanmaktadır. Mahallenin güneybatı bölümünde yer alan Süvari (Nato) Köprüsü ile İstasyon Mahallesine erişim bulunmaktadır.

Konut alanları kapsamında karakteristik konutlarla tariflenmiş sokaklar da, hem bulunduğu semtin hem de kentin kimliğini güçlendirirler. Osmanlı kentinde avlu duvarlarının sürekliliğiyle sokağı tanımlayan cumbalı evler, Londra'daki beyaz teras evler, Bristol'da dökme demir korkuluklu ba lkonlu sira evler, ve Amsterdam'da, giriş katında farklı işlevler içeren, yandan merdivenli girişli, dar cepheli, kademeli çatılı kanal evler, bu kentlerin kimliğinin çok önemli birer bileşeni olmuşlardır (Oktay 2011). Yerleşim olarak birbirine dik ve paralel caddelerden oluşan gridal plan şeması görülmektedir. Yapıların kat yüksekliği analizi incelendiğinde; 1 veya 2 katlı yapıların yoğun olduğu tespit edilmiştir. Bunun yanı sıra daha az sayıda 3 katlı yapılar da bulunmakta ve günümüzde yeni yapılaşma kültürü içerisinde 3 katlı yapı artışları yaşanmaktadır (Şekil 6). Karaağaç Mahallesi içerisinde yer alan konutların; genellikle sokaklar ile doğrudan bir ilişki içerisinde olduğu ve çoğunlukla yapıların ön cephelerinin sokağa açıldığı görülmektedir (Şekil 7). Karaağaç Mahallesi sınırları içinde yer alan ve envanter listelerinde bulunan 59 adet tescilli yapı bulunmaktadır. Karaağaç'taki tarihi konutların çoğunluğunu Rum, Bulgar ve Ermeni ustalar tarafindan yine bu gruplar için yapılmış olan; döneminin kültürünü ve yaşam biçimini yansıtan konutlar oluşturmaktadır (Arabulan, 2015). Yapılar bir bahçe içerisinde yer almaktadır. Bahçelerin yapılar ile ilişkileri incelendiğinde birçoğunun arka bahçe konumunda oldukları belirlenmiştir.

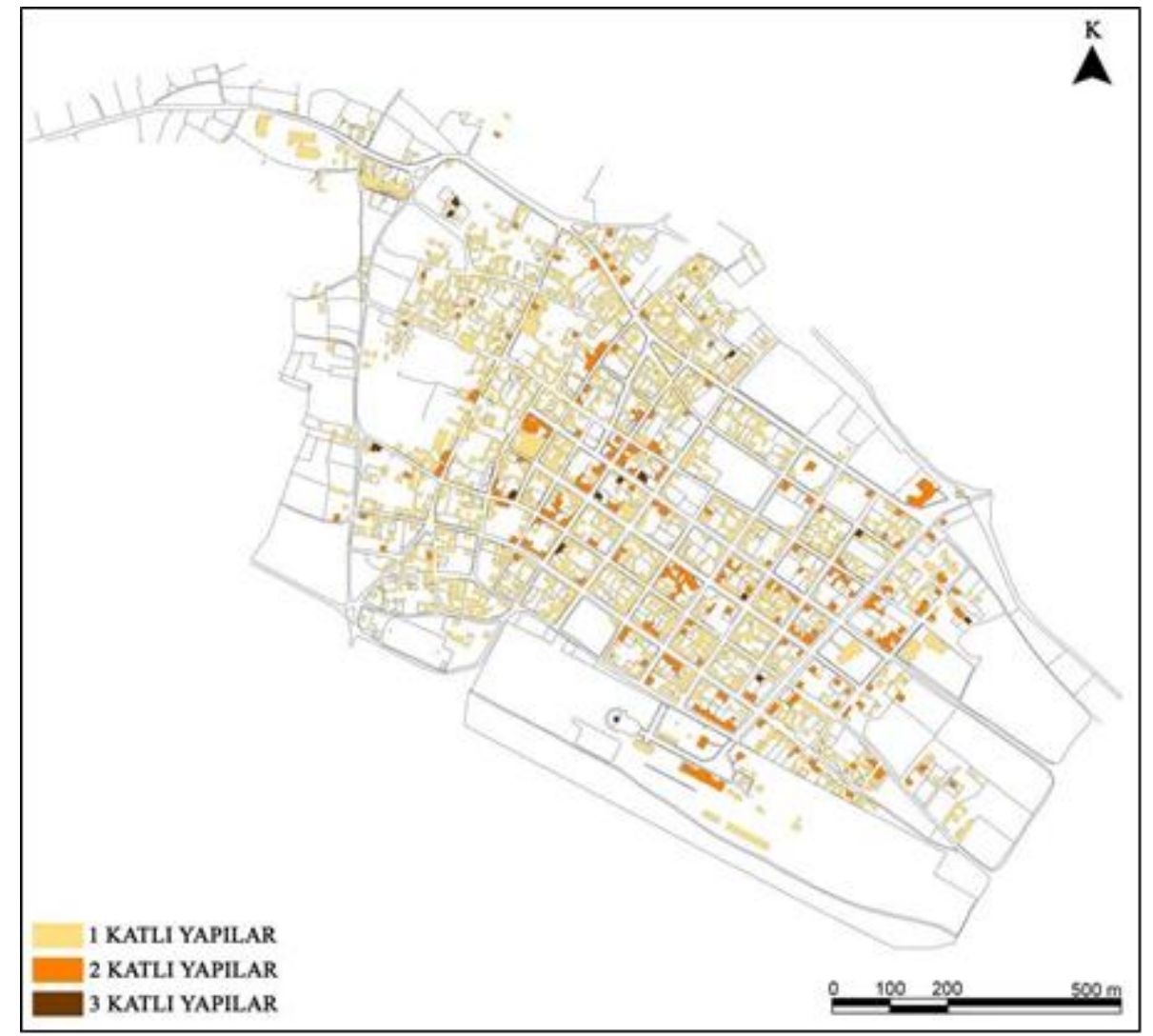

Şekil 6. Çalışma alanı kat yükseklikleri analizi

Karaağaç Mahallesi, Edirne mahalleleri arasında yüzölçümü bakımından en büyük mahalle olmasına rağmen mahalle sınırları içerindeki yerleşim sınırı dardır. Mahallenin doluluk- boşluk analizi incelendiğinde; 125 hektarlık yerleşim sınırı içerisinde ise yapılaşmanın yoğun olduğu görülmektedir (Şekil 8). Nüfus yoğunluğu olarak 3000 ile 4000 nüfuslu mahalleler arasında bulunmaktadır (Şekil 9). Küçük bir mahalle olan Karaağaç’ta 
yaşayan sakinler; çiftçilik, bahçecilik, hayvancılık yaparken, bir kısım da memur olarak çalışmaktadır.
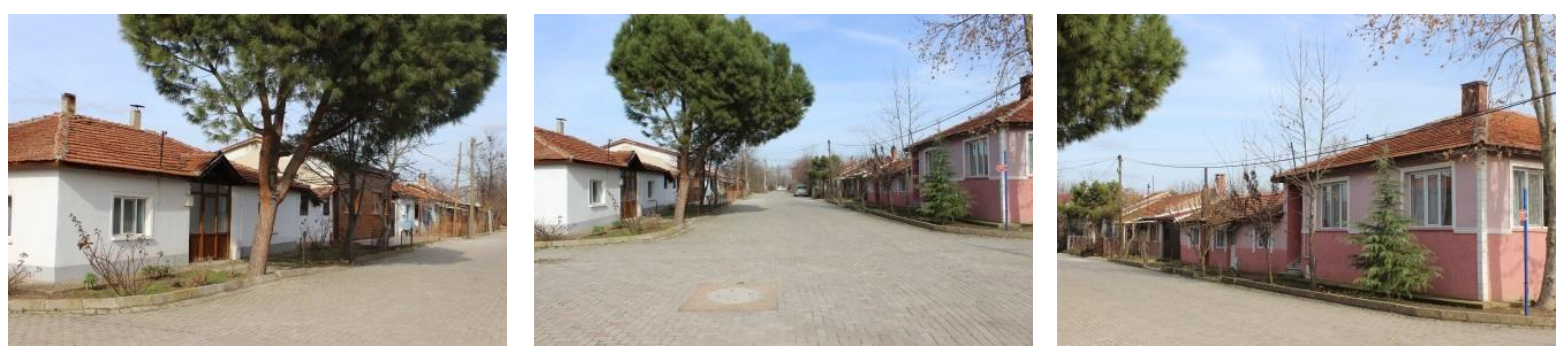

Şekil 7. Dilaver Bey Caddesi’nde yer alan konutların sokak ile ilişkileri

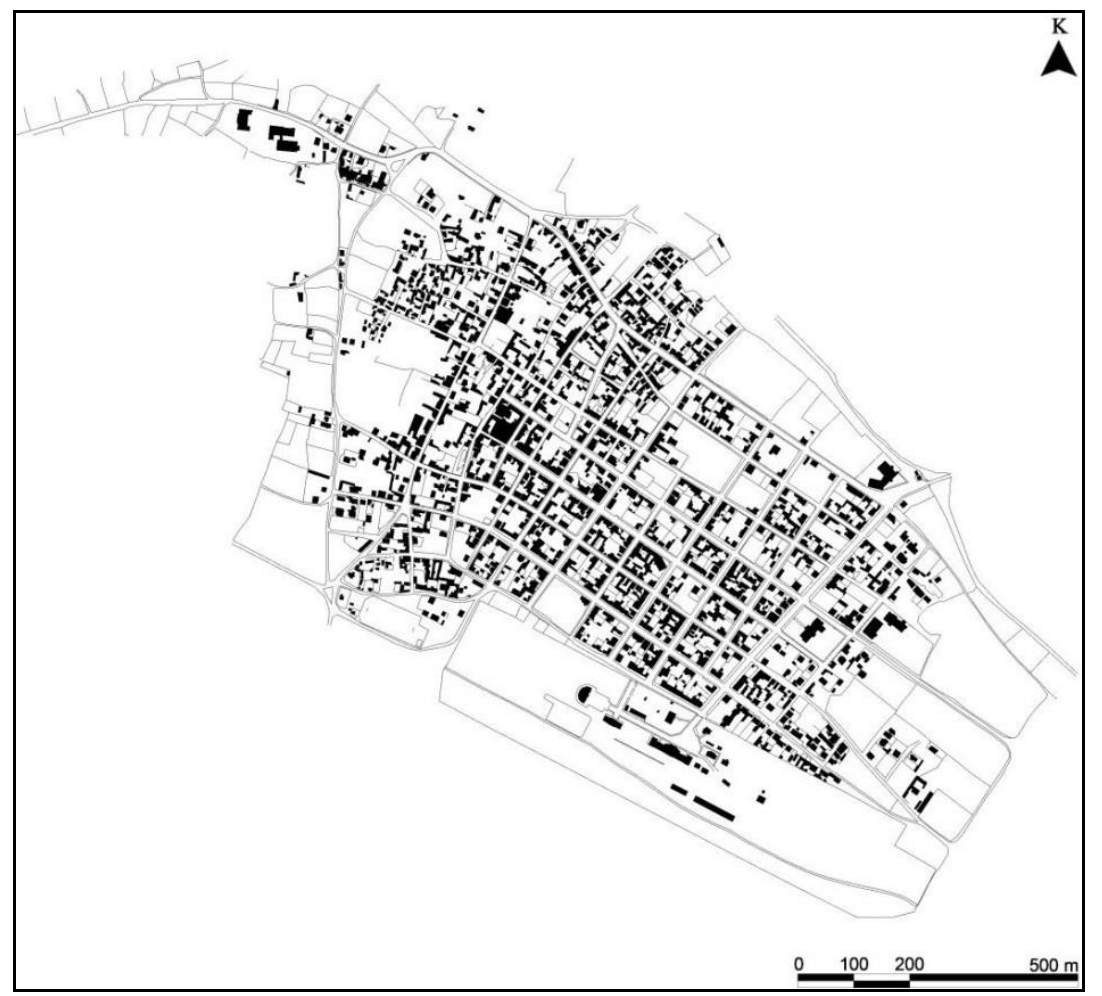

Şekil 8. Karaağaç Mahallesi doluluk-boşluk analizi

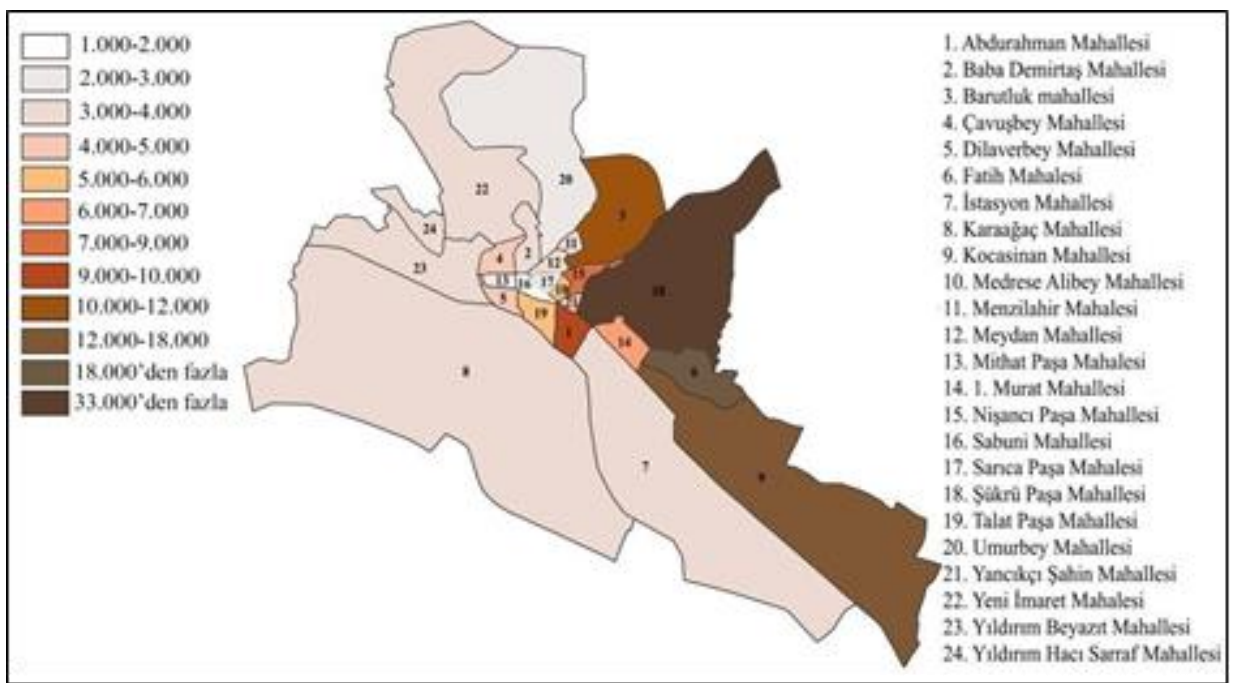

Şekil 9. Edirne mahalleleri nüfus yoğunlukları

Karaağaç Mahallesi'nin 125 hektarlık yerleşim bölgesi içerisinde kalan yaklaşık 50 hektarlık kısmı 30.01.2014 
tarihli Edirne Kültür Varlıklarını Koruma Bölge Kurulu kararı ile kentsel sit alanı ilan edilmiştir (Anonim, 2014). Mahallenin ana arterleri olarak görülen Ressam Hasan Rıza Caddesi ve Ortaköy Caddesi'nin bir bölümü kentsel sit sınırları içerisinde yer almaktadır. Kentsel sit sınırları içerisinde ayrıca tescilli yapılar da bulunmaktadır (Şekil 10). Mahallenin Edirne kent merkezi girişinde yer alan Soğuk Hava Deposu, Mimar Kemallettin tarafindan tasarlanan Tarihi Gar Binası ve ek yapıları, Meriç ve Tunca Köprüleri, Mustafa Necati İlkokulu, Karaağaç Eski Cami tescilli anıtsal yapı (Şekil 11), günümüzde kafeterya işlevi gören Bahattin Öğütmen Konağı, bir süre kafeterya işlevi gören, günümüzde kullanılmayan Laleli Konak gibi yapılar ise tescilli sivil yapılar için örnek gösterilebilir (Şekil 12).

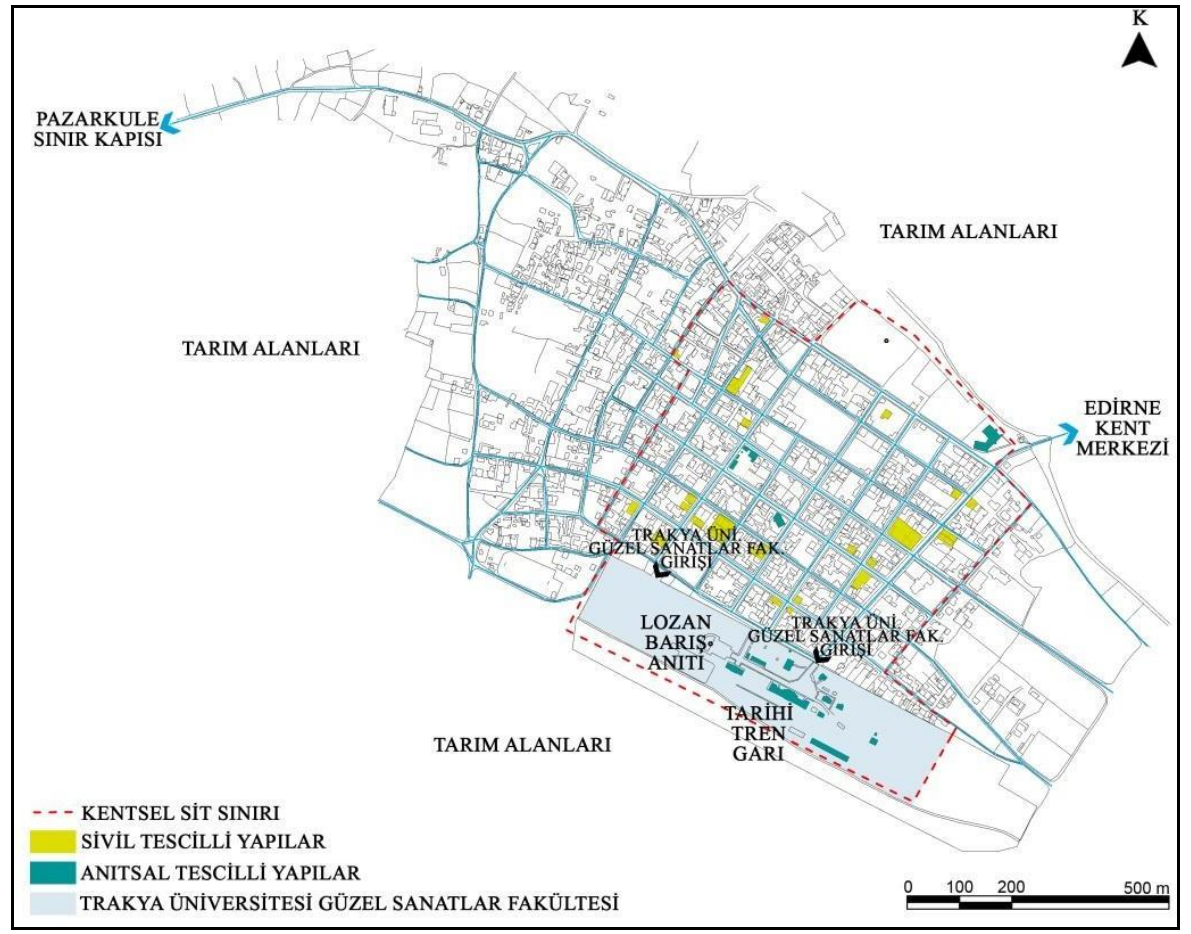

Şekil 10. Çalışma alanı içerisindeki kentsel sit sınırı ve tescilli yapılar analizi
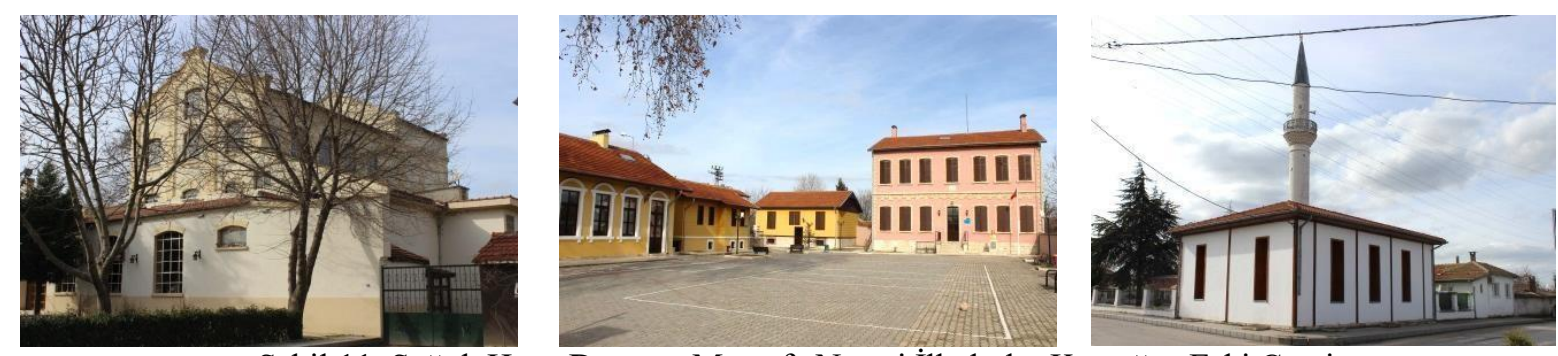

Şekil 11. Soğuk Hava Deposu, Mustafa Necati İlkokulu, Karaağaç Eski Cami
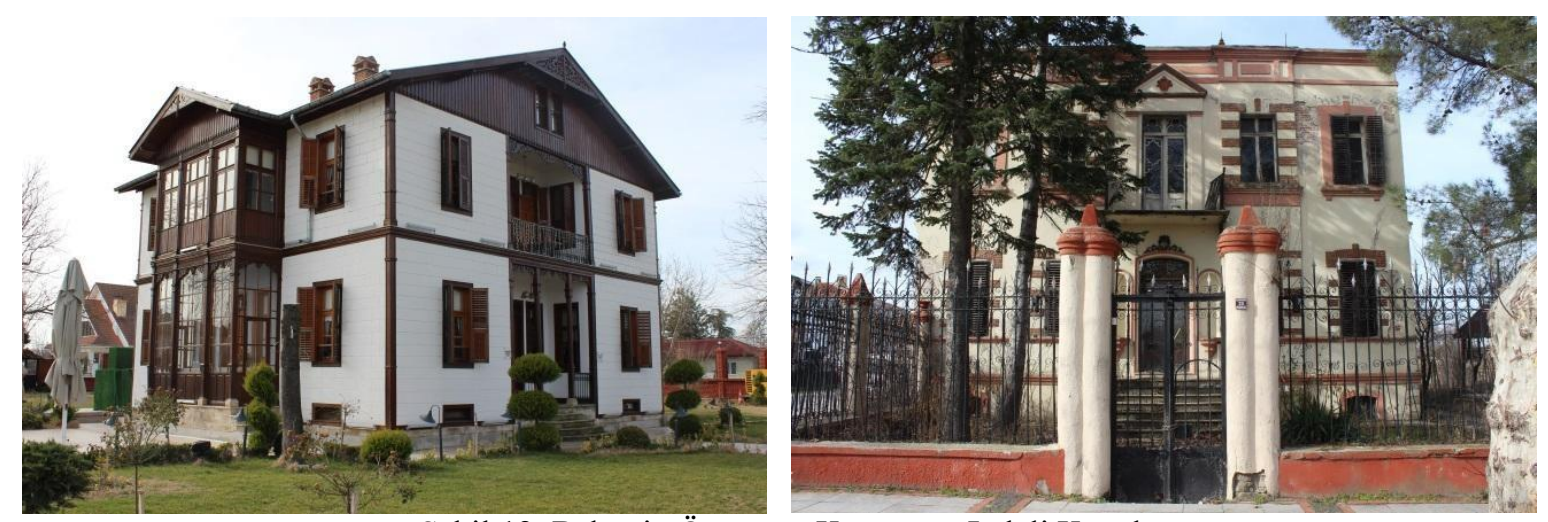

Şekil 12. Bahattin Öğütmen Konağı ve Laleli Konak

Edirne’nin Yunanistan ile sınır kapısını oluşturan Pazarkule Sınır Kapısı'na erişim Karaağaç Mahallesi sınırları 
içerisinden sağlanmaktadır. Yerli ve yabancı turistlerin ülkeye giriş ve çıkış yaptıkları nokta olarak Karaağaç Mahallesi stratejik bir konuma sahiptir. Tarihi Tren Garı, Milli Mücadele ve Lozan Müzesi, İlhan Koman Heykel ve Resim Müzesi ve ek yapılar ile Lozan Barış Anıtı'nın içerisinde yer aldığı Trakya Üniversitesi Güzel Sanatlar Fakültesi mahalle sınırları içerisinde yer almaktadır (Şekil 13). Mahalle için önemli bir odak noktası görevindedir.
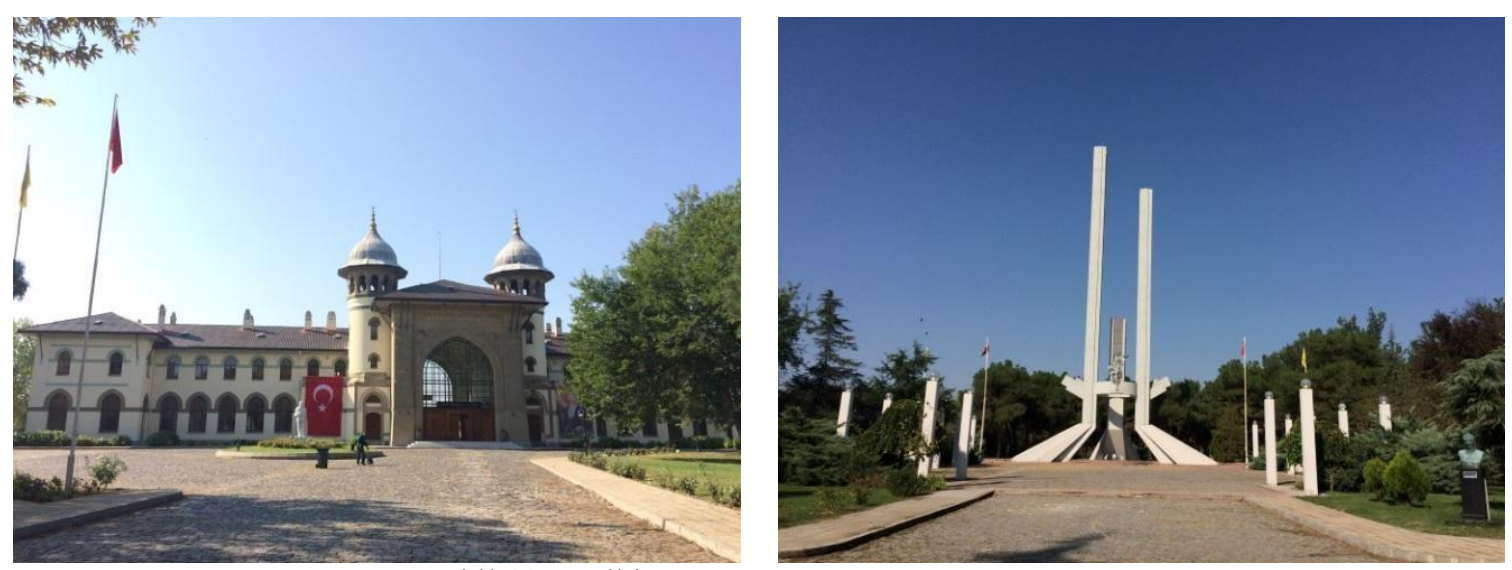

Şekil 13. Tarihi Tren Garı ve Lozan Barış Anıtı

İncelemeler sonucunda Karaağaç Mahallesi için genel bir değerlendirme yapılacak olursa; doğal ve kültürel alanların bir arada bulunması, nehir ve doğal rekreasyon alanlarının bulunması, Lozan Anıtı ve Tarihi Tren Garı'nın yer alması, Trakya Üniversitesi Güzel Sanatlar Fakültesinin yer alması, Pazarkule Sınır Kapısına erişimin sağlanması, trafik yoğunluğunun az olması çalışma alanı ve yakın çevresi için güçlü yönleri oluşturmakta, tanıtımının yetersiz kalması, kent merkezi ile ulaşım bağlantısının zayıf olması, nehir taşkınlarının yaşanması, geleneksel konut dokusunun devam ettirilmemesi, geçim kaynaklarının sınırlı olması ise zayıf yönlerini oluşturmaktadır.

\section{Sonuç ve Öneriler}

Karaağaç Mahallesi, Edirne kenti için özellikli bir alan olarak görülmektedir. Karaağaç; Meriç ve Tunca nehirleri ile Yunanistan ve Türkiye arasında yer alan bir sınır yerleşimidir. Bulunduğu konum dolayısıyla; kültürel, sosyal ve fiziksel yönden kendine özgü bir kimliğe sahiptir. Karaağaç Mahallesi’nin kaybolmuş veya kaybolmaya yüz tutmuş değerlerinin tekrar kazanılması, aynı zamanda var olan değerlerinin de öneminin vurgulanması hem Edirne kenti hem de mahallenin kimlik değerlerini artıracaktır. Yapılan araştırmalar ve elde edilen bulgular doğrultusunda; sahip olduğu kimlik değerleri ile "kültür, tarım ve doğa odaklı" bir yerleşim kimliği kazanmaktadır. Bu anlamda, kimlik vurgusu bütünsellik arz edecek bir şekilde, tarih, kültür, su ve konum gibi bileşenlerle bütünleşmektedir.

Karaağaç Mahallesi, 1923 yılında yaşanan nüfus mübadelesinden sonra mahalle statüsüne geçirilmiş ve günümüzde işlevini sürdürmektedir. Edirne kent merkezine köprüler ile bağlantı kurulan mahalle için tarihte sayfiye yeri olarak kullanılmakla birlikte, günümüzde de bu işlevini sürdürmektedir. Günümüzde şehir merkezine $5 \mathrm{~km}$ uzaklıkta bulunmasıyla şehir içi gürültüsünden uzak olması aynı zamanda araç trafiğinin yoğunluğunun az olması mahallenin olumlu özellikleri arasında yer almaktadır.

Pazarkule sınır kapısına ulaşımın Karaağaç Mahallesi ile sağlanması ülkeye giriş yapan yerli ve yabancı turistler için Türkiye'ye ait ilk izlenimin oluştuğu alandır. Yerleşim alanı içerisinde ise yapılaşmanın yoğun olduğu görülmektedir. Mahallenin, kat analizi incelendiğinde 1 ve 2 katlı yapıların çoğunlukta, 3 katlı yapıların daha azınlıkta olduğu tespit edilmiştir. Tescilli yapıların da yer aldığı mahallede, yapılar, geleneksel dokuları haricinde günümüz inşa teknikleri ve malzemeleri kullanılarak inşa edilmektedir.

Mahalle sınırları içerisinde Trakya Üniversitesi Güzel Sanatlar Fakültesi’nin yer alması ile genç nüfus yoğunluğu artmıştır. Geleneksel özellikleri korunmuş bazı yapılar da dahil olmak üzere birçok yapı, kafe gibi ticari alanlara dönüştürülmüştür. Mahallede, Lozan Barış Anıtı ve Tarihi Tren Garı'nın yer alması yerli ve yabancı turistler için odak noktası konumundadır. Kent merkezinin "tarihi” kent kimliği yanında Karaağaç Mahallesi, doğal ve kültürel özelliklerinin bir arada yer alması ile ön plana çıkarılmalıdır.

Karaağaç Mahallesinde yaşayan halk, geçimini çoğunlukla çiftçilik ile sağlamaktadır. Edirne için önemli bir 
üretim yeri olan Karaağaç Mahallesi’nde, yerel ve organik tarım üretimi desteklenerek, yaygınlığı arttırılmalıdır. Tarihi belgelerde mahallede ipekböcekçiliği yapıldığı belirtilmektedir. Çiftçiliğin yanı sıra tekrar ipekböcekçiliğinin yapılması yeni bir geçim kaynağı oluşumunu destekleyecektir. Aynı zamanda tarihi değerlere sahip çıkılarak, desteklenmesi kültürel özellikleri artıracaktır.

Asker Söğütlüğü Devlet Ormanı, Pazarkule Devlet Ormanı ve Karaağaç Söğütlüğü Devlet Ormanı, mahalle içinde yer alan doğal sit alanlarıdır. Karaağaç Söğütlüğü Devlet Ormanı ise Edirne halkı tarafindan aktif olarak kullanılan rekreasyon alanıdır. Bununla birlikte Meriç Nehri’ne paralel olarak konumlanması, çekiciliğini arttıran bir diğer özelliğidir.

Karaağaç Mahallesi için turizm ve tarım değerlerinin tam anlamıyla kullanılamaması ortaya yönetim ve tanıtım sorununu çıkarmaktadır. Bu sorunlar için çözümler üretilmelidir. Gerekli tanıtımların yapılması Edirne İli genelinde katkı sağlayacaktır. Bunun için başta kamu ve özel sektör olmak üzere sivil örgütlerle iş birliği yapılması öngörülebilir.

Tüm bunların yanında sosyal yatırımların yapılması, eğitim kapasitesinin arttırılması katkı sağlayacaktır. Yerel halkın geçim kaynağı olan çiftçilik, hayvancılık ile ilgili eğitim ve bilinçlendirme seminerleri düzenlenebilir. Yetiştirilen ürünlerin tohumları organik tarım için özel üretilerek, tohum bankası gibi özellikli projeler hayata geçirilebilir. Üretim aşamasında suyun etkin kullanımının sağlandığı sulama sistemlerinin seçimine dikkat edilebilir. Yenilenebilir enerji kaynaklarının kullanımı sağlanarak sürdürülebilirliğe de katkı sağlanacaktır.

$\mathrm{Bu}$ tespitler sonucunda çalışma alanı ve yakın çevresi için şu öneriler geliştirilmiştir;

- Tarih, kültür, su ve konum gibi bileşenlerle bütünleşen Karaağaç'ın sahip olduğu bu mirasın Edirne kent bütünü çerçevesinde korunması ve geliştirilmesine yönelik planlama yaklaşımı ele alınmalıdır.

- Farklılık yaratan yerel özellikleri ( sınır özelliği, Meriç ve Tunca Nehirleri, sivil mimari ve anıtsal yapıları, doğal sit alanları vb.) planlama ve kentsel tasarım çalışmalarına dahil edilerek ön plana çıkarılmalıdır.

- Mimari tasarımda geleneksel yapılaşma kültürü ve yerel kimlik değerlerini esas alan yaklaşım ele alınmalıdır. Bu anlamda, kentin gridal dokusu yol ve yapılaşma biçiminde korunarak, yerel malzeme kullanımını özendiren az katlı bir yapı yaklaşımı ele alınmalıdır.

- Geleneksel yapılardan bazılarının butik otel, sanat atölyesi, geleneksel el sanatlarına yönelik mekanlar gibi farklı işlevlerle çeşitlendirilmesi sağlanabilir.

- Kültür ve doğa odaklı ekonomik çeşitlenme kapsamında, yerel ve organik tarımsal üretimin desteklenerek, yaygınlığının arttırılması sağlanmalıdır.

- Meriç Nehri'nde yaşanan taşkın sorunları için alternatif çözümlerin üretilerek işlevsel ve sürdürülebilir kullanıma yönelik yaklaşımlar ele alınmalıdır.

- Alanın tanıtımına önem verilmesi ve marka değeri yaratacak ürün ve elemanların değerlendirilerek imaj oluşumunun güçlendirilmesi sağlanmalıdır

- Merkezi ve yerel yönetim ile özel sektör olmak üzere sivil toplum örgütleri, üniversiteler ve yerel halk ile işbirliği çerçevesinde katılımcı bir anlayış benimsenmelidir.

Sonuç olarak; Karaağaç yerleşiminin yere1 kimlik değerlerinin ön plana çıkarılarak, özgün dokusunun korunarak Edirne kent bütünü içerisinde sürdürülebilirliğinin sağlanması oldukça önemlidir.

\section{Kaynaklar}

1. Anonim (2014). T.C. Kültür ve Turizm Bakanlığı Edirne Kültür Varlıklarını Koruma Bölge Kurulu, 30.01.2014 tarihli, 1492 numaralı karar.

2. Arabulan S (2015). Kentsel Dönüşüm Kapsamında Kimliğin Yeniden Kazanımı: Edirne- Karaağaç Örneği. Trakya Üniversitesi Fen Bilimleri Enstitüsü, Mimarlık Anabilim Dalı, Doktora Tezi, 241s.

3. Benli G, Özer DG (2018). Kent Kimliğinin Tanımlanmasında Kültür Envanterinin Rolü: Bitlis Sivil Mimarisi. Uluslararası Hakemli Tasarım ve Mimarlık Dergisi, (13), 92-124.

4. Bulut Y, Atabeyoğlu Ö (2010). Kent Planlamasında Peyzaj Mimarlarının Yeri ve Önemi. III. Ulusal Karadeniz Ormanc1lık Kongresi, s:1494-1503, 20-22 Mayıs, Artvin.

5. Çetinkaya G, Uzun O (2014). Peyzaj Planlama. Birsen Yayınevi, İstanbul, 219s.

6. Çöl Ş (1998). Kentlerimizde Kimlik Sorunu ve Günümüz Kentlerinin Kimlik Derecesini Ölçmek İçin Bir Yöntem Denemesi. Mimar Sinan Üniversitesi Fen Bilimleri Enstitüsü Şehir ve Bölge Planlama Bölümü Kentsel Tasarım Dalı Doktora Tezi. http://www.solencol.com/doktez.html (20.06.2018). 
7. Demir C (2006). Kent Kimliği Geliştirme Sürecinde Mekansal Model Tasarımı ve Kent Plancılarının Rolü. Planlama Dergisi, 37(3), 117-122.

8. Edirne Orman Genel Müdürlüğü Arşivi (2017). Sözlü Görüşme ve veri temini.

9. Emekligil Erdoğu R (2013). "Geçmişin İzinde Karaağaç", Edirne Valiliği Kültür Yayınları, Birinci Bask1.

10. Etli B, Şişman E (2004). Edirne Söğütlük Ormanı Rekreasyonel Potansiyeli ve Kullanım Olanaklarının Geliştirilmesi Üzerinde Bir Araştırma. I. Ulusal Kent Ormancılığı Kongresi, s: 157-169, 9-11 Nisan 2004, Kırsal Çevre ve Ormancılık Sorunları Araştırma Derneği, Türkiye Ormancılar Derneği, TMMOB Peyzaj Mimarları Odası, TMMOB Çevre Mühendisleri Odası, Ankara.

11. Gül A (2000). Peyzaj- İnsan İlişkisi ve Peyzaj Mimarlığı. Süleyman Demirel Üniversitesi Orman Fakültesi Dergisi, A(1), 97-114.

12. Güneroğlu N, Bekar M (2017). Dönüşüm ve Kimlik Kavramı: Trabzon Örneği. Kastamonu Üniversitesi, Orman Fakültesi Dergisi, 17(4), 580-593.

13. Hernandez L (2007). The Loss of an Ordinary Landscape, New Plymouth District Council.

14. ICOMOS (2008). Québec Declaration on the Preservation of the Spirit of Place, Québec.

15. Karakaya Aytin B, Ertin DG, Özyavuz M (2016). Kent Kimliğinin Edirne Kaleiçi Yerleşim Alanı Özelinde Değerlendirilmesi. 4. Uluslararası Kentsel ve Çevresel Sorunlar ve Politikalar Kongresi, s:81- 102, 20-22 Ekim, İstanbul.

16. Karaşah B (2017). Kentsel ve Kırsal Rekreasyon Alanlarına Yönelik Kullanıcı Tercihlerinin Belirlenmesi ‘Artvin Kenti Örneği’. Bartın Orman Fakültesi Dergisi, 19(1), 58-69.

17. Kaya E (2017). Kentleşme ve Kentlileşme. İşaret Yayınları, İstanbul, $216 \mathrm{~s}$.

18. Kiper T, Öztürk AG (2011). Kent Ormanlarının Rekreasyonel Kullanımı ve Yerel Halkın Farkındalığı: Edirne Kent (İzzet Arseven) Ormanı Örneği. Tekirdağ Ziraat Fakültesi Dergisi, 8(2), 105-118.

19. Koyuncu A (2013). Kimliğin İnşasında Kent: Konya Örneği. Akademik İncelemeler Dergisi, 8(2), $155-179$.

20. Lynch K (1960). The Image of The City. The Tecnology Pres\&Harvard University Pres, Cambridge, $194 \mathrm{p}$.

21. Misırlı A, Benian E (2014). Evaluation of the Historical City Edirne Through Cultural Assets. Humanities and Social Sciences Review, 3(2), 309-325.

22. Neill, WJV (1997). Memory, Collective Identity and Urban Design: The Future of Berlin's Palast Der Republik. Journal of Urban Design, 2(2), 179-192.

23. Ocakçı M (1994). Şehrin Kimliği ve Çevre İlişkileri. Kent ve Çevre Planlamaya Ekolojik Yaklaşım. Dünya Şehircilik Günü Kolokyumu Kitapçığı, ss.163-170, MSGSÜ, İstanbul.

24. Oktay D (2011). Kent Kimliğine Bütüncül Bir Bakış. İdeal Kent, 3, 8-19.

25. Önem AB, Kılınçaslan İ (2005). Haliç Bölgesinde Çevre Algılama ve Kentsel Kimlik. İTÜ Dergisi/a, Mimarlık, Planlama ve Tasarım, 4(1), 115-125.

26. Özkök MK (2016). Planlama Öğrencileri Gözünden Kent Kavramına Yönelik Bir Değerlendirme. Dünya Şehircilik Günü 8. Türkiye Şehircilik Kongresi, 7-8-9 Kasım, Orta Doğu Teknik Üniversitesi, Ankara.

27. Öztürk Tel H, Erdoğan E (2014). Ekolojik Yerleşmeler ve Ekolojik Yıpranma: Şanlıurfa Geleneksel Kent Dokusu ve Karaköprü İlçesi. KSÜ Doğa Bilimleri Dergisi, 17(1), 21-31.

28. Ringas D, Christopoulou E, Stefanidakis M (2011). Urban Memory in Space and Time. Styliaras G, Koukopoulos D, Lazarinis F (Eds.), Handbook of Research on Technologies and Cultural Heritage. Information Science Reference, New York.

29. Tekeli İ (1990). Bir Kentin Kimliği Üzerine Düşünceler. Prof. Dr. Mübeccel Kıray'a Armağan, Marmara Üniversitesi İktisadi ve İdari Bilimler Fakültesi Dergisi, VII (1-2), 251-259.

30. Topçu KD (2011). Kent Kimliği Üzerine Bir Araştırma: Konya Örneği. Uluslararası İnsan Bilimleri Dergisi. 8(2), 1048-1072. 